\title{
WILL ‘OTHER EFFECTIVE AREA-BASED CONSERVATION MEASURES' INCREASE RECOGNITION AND SUPPORT FOR ICCAS?
}

\author{
Harry D. Jonas ${ }^{1 *}$, Emma Lee ${ }^{2}$, Holly C. Jonas ${ }^{3}$, Clara Matallana-Tobon ${ }^{4}$, \\ Kim Sander Wright ${ }^{3}$, Fred Nelson ${ }^{5}$ and Eli Enns ${ }^{3}$ \\ *Corresponding author: harry@naturaljustice.org \\ ${ }^{1}$ Natural Justice, Cape Town, South Africa \\ ${ }^{2}$ Centre for Marine Socioecology, University of Tasmania, Hobart, Tasmania, Australia \\ ${ }^{3}$ ICCA Consortium, Bugnaux (Essertines-sur-Rolle), $\mathrm{CH} 1180$, Canton de Vaud, Switzerland \\ ${ }^{4}$ Humboldt Institute, Bogota D.C. PBX: 3202767, Colombia \\ ${ }^{5}$ Maliasili Initiatives, Underhill VT 05489, USA
}

\section{ABSTRACT}

This paper reflects on IUCN's ongoing progress to develop technical guidance on 'other effective area-based conservation measures' (OECMs) and begins to explore under what conditions OECMs - as a new form of recognition - might make a positive contribution to territories and areas conserved by Indigenous peoples and local communities (abbreviated to 'ICCAs'). It argues that while the protected areas framework is a potentially useful means by which to recognise the biodiversity contributions of some ICCAs, it is not universally appropriate. In this context, and subject to important caveats, OECM-related frameworks offer an important opportunity to increase recognition and support for ICCAs. The paper concludes with two practical recommendations: first for the development of supplementary guidance on OECMs and ICCAs; and second, for further discussion by a wide range of interested parties on whether 'OECMs' should be referred to as 'conserved areas'.

Key words: Aichi Biodiversity Targets, protected areas, other effective area-based conservation measures, Indigenous peoples and local communities, ICCAs, conserved areas

\section{INTRODUCTION}

In the closing hours of the $10^{\text {th }}$ Conference of the Parties to the Convention on Biological Diversity (COP/CBD), Parties finalised their negotiations of Aichi Target 11, which resulted in the following formulation:

By 2020, at least 17 per cent of terrestrial and inland water, and 10 per cent of coastal and marine areas, especially areas of particular importance for biodiversity and ecosystem services, are conserved through effectively and equitably managed, ecologically representative and well connected systems of protected areas and other effective area-based conservation measures, and integrated into the wider landscapes and seascapes. (Emphasis added).

This was the first appearance of the term 'other effective area-based conservation measures' (OECMs), and over the following four years, discussions within CBD fora and the International Union for Conservation of Nature (IUCN) underscored the need for guidance on the matter, including in relation to the potential for making a direct link between OECMs and ICCAs (see, for example Lopoukhine and de Souza Dias, 2012; IUCN, 2012a; IUCN, 2012b; Woodley et al., 2012; CBD, 2013; CBD, 2014). ${ }^{1}$

In 2015, and in line with the recommendation of several of the authors of this paper (Jonas et al., 2014), the WCPA established a Task Force to "develop guidance for IUCN members and CBD Parties on the definition of 'other effective area-based conservation measures". ${ }^{2}$ At the time of writing (November 2017) the draft definition of OECMs used by the Task Force is as follows:

"A geographically defined space, not recognised as a protected area, which is governed and managed over the long-term in ways that deliver the effective and enduring in-situ conservation of biodiversity, with associated ecosystem services and cultural and spiritual values." (IUCN-WCPA, 2017a).

The core difference between this definition and the IUCN definition of a protected area ${ }^{3}$ is that protected areas must have conservation as the primary objective of management but OECMs are defined by outcomes rather 
than objectives: an OECM must deliver the effective and enduring in-situ conservation of biodiversity and this is regardless of the management objectives.

This paper explores under what conditions recognition as OECMs might make a positive contribution to territories and areas conserved by Indigenous peoples and local communities (ICCAs). Even though the concept of ICCAs in policy and academic writing is a recent phenomenon, sites of this kind have been in existence since humans began to govern and manage landscapes and seascapes purposefully. They are referred to by a wide range of terms in their local contexts. Underpinned by cultural, spiritual, economic, political and other motivations, they are the basis of survival, livelihoods, identity, and wellbeing for millions of people (Kothari \& Neumann, 2014).

ICCAs are one of four governance types of both protected areas and OECMs (see Table 1) and are defined by three essential characteristics:

- An Indigenous people or local community possesses a close and profound relationship with a site (territory, area or habitat);

- $\quad$ The people or community is the major player in decision-making related to the site and has de facto and/or de jure capacity to develop and enforce regulations; and

- The people's or community's decisions and efforts lead to the conservation of biodiversity, ecological functions and associated cultural and spiritual values, regardless of original or primary motivations. (Borrini-Feyerabend, 2010; BorriniFeyerabend et al., 2014).

The third characteristic specifies that like OECMs (and in contrast to IUCN protected areas), ICCAs are defined by outcomes rather than objectives: decisions and efforts must lead to conservation "regardless of ... motivations". Therefore not all ICCAs will be eligible for recognition as protected areas, but those that are not may still qualify as OECMs.

Returning to OECMs, the draft Guidelines set out three types of approaches that can lead to OECMs, subject to consent by the area's governance authority (discussed below). These include: areas where conservation is the primary management objective (primary conservation) that may meet all elements of the IUCN definition of a protected area, but which are not officially recognised as such because the governance authority does not want the area to be designated as a protected area; areas where conservation is an outcome of management but is a secondary management objective (secondary conservation), which therefore do not meet the IUCN definition of a protected area; and areas that deliver conservation outcomes as a by-product of management activities even though biodiversity conservation is not a management objective at all (ancillary conservation). All three types of OECM-related approaches have clear relevance for ICCAs (IUCN-WCPA, 2017a).

\section{ICCAS REQUIRE GREATER RECOGNITION AND SUPPORT}

It is estimated that ICCAs equal or exceed the number and extent of state protected areas (Kothari et al., 2012) and there is increasing evidence that under certain conditions (Ostrom, 1990, 2000), areas and resources under the governance and/or management of Indigenous peoples and local communities can be, with certain scalespecific qualifications (Shahabuddin \& Rao, 2010), as or more effective than strictly protected areas at preventing deforestation, maintaining forest health and ecosystem connectivity, and conserving biodiversity and natural resources (Kothari et al., 2000; Lovgren, 2003; Molnar

Table 1. The continuum of governance types across IUCN protected areas and OECMs, with illustrative examples $^{4}$

\begin{tabular}{|c|c|c|c|c|}
\hline $\begin{array}{l}\text { Governance types } \\
\text { Form of } \\
\text { conservation } \downarrow\end{array}$ & $\begin{array}{l}\text { Governments (at } \\
\text { various levels) }\end{array}$ & $\begin{array}{c}\text { Private individuals, } \\
\text { organisations and } \\
\text { companies }\end{array}$ & $\begin{array}{l}\text { Indigenous peoples } \\
\text { and/or local } \\
\text { communities }\end{array}$ & Shared \\
\hline Protected Areas & $\begin{array}{l}\text { A government } \\
\text { national park }\end{array}$ & $\begin{array}{l}\text { A privately owned } \\
\text { wetland managed } \\
\text { primarily for its } \\
\text { conservation values }\end{array}$ & $\begin{array}{l}\text { An Indigenous or } \\
\text { community forest } \\
\text { managed primarily for its } \\
\text { conservation values }\end{array}$ & $\begin{array}{l}\text { Any of the kinds of } \\
\text { areas listed to the left } \\
\text { (among others) where } \\
\text { governance is shared }\end{array}$ \\
\hline OECMs & $\begin{array}{l}\text { A government water } \\
\text { conservation area } \\
\text { that contributes to } \\
\text { biodiversity } \\
\text { conservation as a } \\
\text { secondary objective }\end{array}$ & $\begin{array}{l}\text { A privately owned } \\
\text { disused quarry that } \\
\text { provides avian } \\
\text { habitat as a by- } \\
\text { product of the area's } \\
\text { exclusion of activities. }\end{array}$ & $\begin{array}{c}\text { An Indigenous or } \\
\text { community sacred grove } \\
\text { that prohibits } \\
\text { destructive activities for } \\
\text { spiritual reasons }\end{array}$ & $\begin{array}{l}\text { Any of the kinds of } \\
\text { areas listed to the left } \\
\text { (among others) where } \\
\text { governance is shared }\end{array}$ \\
\hline
\end{tabular}


et al., 2004; White et al., 2004; Hayes \& Ostrom, 2005; Nepstad et al., 2006; Nagendra, 2008; World Bank, 2008; Bray et al., 2008; Nelson \& Chomitz, 2011; PorterBolland et al., 2011; Nolte et al., 2013; CIPTA \& WCS, 2013; Stevens, 2014). In the context of the downward trends in global biodiversity (UNEP-WCMC and IUCN, 2016; Ceballos et al., 2017), therefore, appropriately recognising and supporting ICCAs becomes ever more important.

Yet ICCAs and their custodians are under threat from multiple sources, including the influence of traditional systems of mainstream economies, languages, education and health care systems, media and religions (United Nations, 2009; International Work Group for Indigenous Affairs, 2017); imposed forms of 'development' such as industrial agriculture, extractive industries and physical infrastructure in both terrestrial (Coalition Against Land Grabbing, 2015) and marine contexts (Bennett et al., 2015); armed conflicts and establishment of illegal crops due to a growing demand for drugs (IDMC, 2017); and displacement of Indigenous peoples from their traditional territories as a result of exclusionary forms of conservation (Adams \& Mulligan, 2004; Dowie, 2009; Indian Law Resource Centre and IUCN, 2015). In many instances, laws (such as those related to weak tenure rights), judicial processes and related institutions facilitate and protect the interests of more powerful groups against Indigenous peoples and local communities (Minority Rights Group, 2012; Rights and Resources Initiative, 2012). Associated violence against environmental and human rights defenders (including 200 reported murders in 2016) is occurring at an alarming rate (Global Witness, 2017).

Respecting and supporting Indigenous peoples and local communities who choose to steward, govern, manage or otherwise control the territories and areas they depend upon securely is a human rights imperative that also supports the integrity of ecosystem functions and the conservation of biodiversity (Tauli-Corpuz, 2016; Knox, 2017). Towards this end, Indigenous peoples and local communities continue to gain hard-fought recognition of a broad range of rights, across multiple laws and policy statements at the international and national levels (Jonas, 2012; Jonas, 2016), all of which are critical to their social, cultural, spiritual and ecological integrity. Indigenous peoples and local communities have made significant international legal gains within the CBD relating to conservation, customary sustainable use of biodiversity, and traditional knowledge, including in dedicated processes on Articles 8(j) and 10(c). In the protected areas context, major breakthroughs at the international policy level include the development of the CBD's Programme of Work on Protected Areas (2004) and several CBD COP decisions on protected areas since then, as well as adoption by the IUCN of four protected areas governance types, including governance 'by Indigenous peoples and local communities' (Phillips, 2004; Dudley, 2008; Borrini-Feyerabend et al., 2013; Worboys et al., 2015).

Despite these advances, and subject to the caveats in Box 1, in 2017 the World Database on Protected Areas included only 1,351 protected areas that were governed by Indigenous peoples and local communities. This stands in contrast to 186,391 protected areas governed by governments. 5 The former amounts to an area of $1,896,321.7 \mathrm{~km} 2$, which is under 5 per cent of the total area of terrestrial and marine protected areas (UNEPWCMC \& IUCN, 2017).

\section{Box 1. Placing the WDPA data on ICCAs in context}

The data held by the WDPA on ICCAs, referenced above, should be read in the context of two important caveats. First, despite the global nature of such protected areas, the reporting of such areas is from only 27 countries and territories, and Brazil's level of reporting of such protected areas (499 areas) accounts for more than one third of the total. This suggests that the current global levels of reporting of protected areas governed by Indigenous peoples and local communities are significantly lower than the total number of areas that may meet the definition. This presumption is bolstered by unofficial figures that suggest Indigenous peoples alone strongly influence governance of over a third of all lands designated as protected areas and that a fifth of all Indigenous lands are listed as protected areas (Garnett, pers. comm.). For example, in Australia, 75 Indigenous Protected Areas cover approximately 67 million hectares, which comprise 44 per cent of the National Reserve System and 7.5 per cent of all protected areas in Australian territories (CAPAD, 2014). This figure does not include jointly-managed World Heritage Areas, such as Kakadu National Park (Lee, 2016a). Second, a number of the protected areas within which Indigenous peoples and local communities have an important influence are reported as 'shared governance'. It is also important to note that, despite the principle that reporting of protected areas should be undertaken on the basis of the free, prior and informed consent of the respective governance authority (Borrini-Feyerabend et al., 2014), it is likely that not all data-providers reporting to the WDPA follow this principle (Stevens et al., 2016a; Stevens et al., 2016b). 


\section{POTENTIAL MISALIGNMENT BETWEEN}

\section{PROTECTED AREAS AND ICCAS}

Despite these advancements, ICCAs still sit uncomfortably or even in direct conflict with protected areas in many national contexts. Recent reports by two UN Special Rapporteurs - the first on the rights of Indigenous peoples and the second on human rights and the environment - clearly set out the historical and present day injustices suffered by Indigenous peoples and local communities in the context of conservation initiatives (Tauli-Corpuz, 2016; Knox, 2017).

At one level, injustices continue to occur because, among other things, many national-level protected areas frameworks have failed to keep up with international advances in human rights and environmental law and jurisprudence (Kothari et al., 2012; Stevens, 2010; Stevens, 2014; Rights and Resources Initiative, 2015). The result is that many national conservation frameworks either do not provide for the recognition of ICCAs - including in situations of overlap with protected areas (Stevens, 2014; Stevens et al., 2016a; Stevens et al., $2016 \mathrm{~b}$ ) - or do so in ways that some Indigenous peoples' or communities' governing authorities ${ }^{6}$ deem inappropriate or in violation of their human rights (Burnham, 2000; Poirier \& Ostergren, 2002; Brockington \& Igoe, 2006; Phyälä, 2016).

At a deeper, structural level, the seeds of these injustices were sown into 'conservation' at its founding in the form of game reserves and national parks in the nineteenth century (Stevens, 1997; Colchester, 2003; Adams \& Mulligan, 2004; Dowie, 2009, Stevens, 2014). Through a lens that prioritises biodiversity, Indigenous peoples' and local communities' connections to land, sea and sky have long been delineated in conservation policy as being either 'natural' or 'cultural'. This has led in many instances to the objectification of cultural values (Cohen, 1978; Lee, 2016a) and the associated undervaluing and undermining of the broader and more intricate socialecological systems (Berkes et al., 2003; Folke et al., 2005) and relationships that exist across landscapes and seascapes with which Indigenous peoples and local communities have close connections (Pathak, 2009; Robson \& Berkes, 2010; Brown \& Kothari, 2011; Bhatt et al., 2012; AIPP, 2013).

This approach has led to holistic and inextricably linked forms of culture, spirituality, knowledge and practices being presented as "those that contribute to conservation outcomes" (Dudley, 2008) and those that do not. According to this approach, Indigenous peoples' and local communities' worldviews matter, but only if they accord with what is desired and acceptable within a protected areas framework (Wilk, 1995; Morel, 2010). While this approach may have an inherent logic from a 'conservation' perspective, this binary approach leaves a wealth of Indigenous and local worldviews (including ontologies and ethics) unrecognised, disrespected and marginalised (Indian Law Resource Centre and IUCN, 2015). Inherent values that are characterised by the variability of diverse, changing and complex connections to both the physical and non-physical worlds (Gibbs, 2006; Johnson \& Morton, 2007) and relational ways of knowing (Healey \& Tagak, 2014) are obscured by the poor fit into either 'natural' or 'cultural' values (Lee, 2016a).

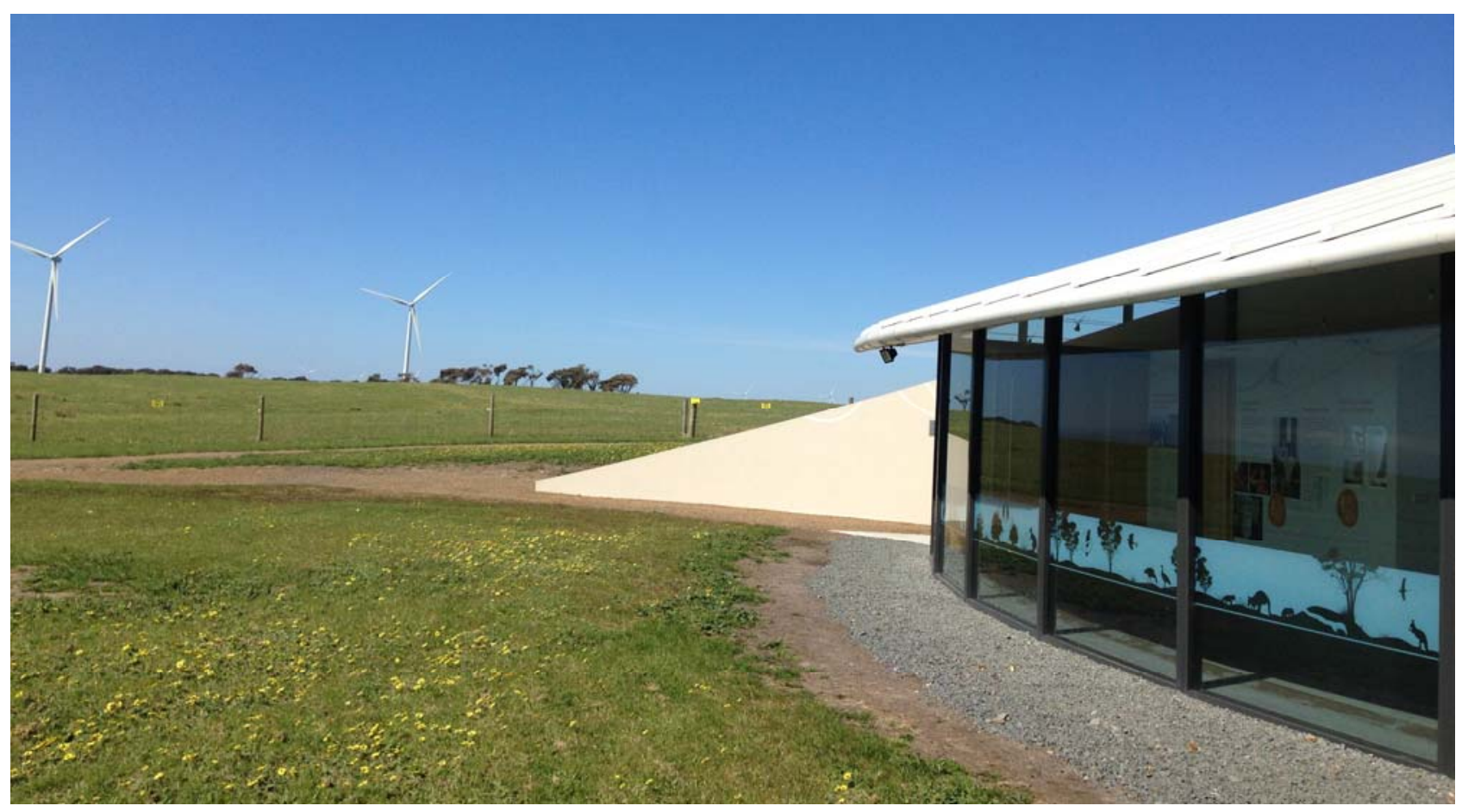

Tebrakunna Visitors Centre, Tasmania @ Hilary Burden 
The issues set out above have been the subject of CBD deliberations and are widely referenced in - among other places - IUCN World Parks Congresses' outcome documents such as the Durban Accord (IUCN, 2003), the Promise of Sydney and New Social Compact (IUCN, 2014a; IUCN, 2014b), and other international instruments (Tauli-Corpuz, 2016; Knox, 2017). To address past wrongs and establish just approaches to conservation (Greiber et al., 2009; Kashwan, 2013), many national protected area frameworks are undergoing reforms to ensure their adherence to international and regional human rights norms. The advent of OECMs - as a body of technical guidance, laws, institutional frameworks and practices operating at the international and (sub-)national levels - has the potential to augment that encouraging trend. First, they may be a useful means by which to provide an additional layer of recognition to ICCAs that either do not meet the definition of a protected area or do not want to be recognised as such. The effectiveness of this approach will be contingent on governmental and private actors respecting and supporting OECMs, which is not a given, considering alarming trends towards protected area downgrading, downsizing and degazettement 7 may also extend to OECMs. Second, if crafted sensitively and with wisdom, OECMs have the potential to directly address the foundational misalignment between Indigenous peoples' and local communities' traditional approaches to territories, land and sea, on the one hand, and Western scientific (often dualist) approaches to conservation, culture and nature on the other. The nuances of these statements are elaborated in the next section.

\section{RECOGNISING OECMS, RESPECTING ICCAS}

There are several potential benefits of recognising OECMs as a complement to protected areas (IUCNWCPA, 2016a, 2016b, 2017b; Juffe-Bignoli et al., 2016; Diz et al., 2017; Laffoley et al., 2017), including: increasing the potential to engage and support a range of new partners in global conservation efforts; incentivising the recognition or application of robust conservation and management measures to areas of biodiversity significance; and contributing to improved management and restoration of areas that could usefully support longterm in situ conservation of biodiversity. The latest Protected Planet Report adds to this list, stating that: "In the long term, OECMs could have the potential to contribute greatly to elements such as representativeness and connectivity, and to contribute to conservation in important places such as KBAs [key biodiversity areas], especially in cases where protected areas are not an option" (UNEP-WCMC \& IUCN, 2016). This section provides a preliminary analysis of the issues relevant to the future recognition of some ICCAs as OECMs.

\section{Equality of standing between conservation measures}

The relative value of OECMs vis-à-vis protected areas is a key issue that has been discussed within and beyond the OECM Task Force (IUCN-WCPA, 2015, 2016a; BorriniFeyerabend, 2016). The deliberations are clear that while protected areas and OECMs are mutually exclusive frameworks, both have value for biodiversity conservation. In doing so, OECMs have the potential to advance the international recognition of the in situ conservation of biodiversity outside protected areas,

\section{Example 1. Tebrakunna Visitors Centre, Tasmania}

On tebrakunna ${ }^{7}$ country, northeast Tasmania, Australia, traw/wulwuy peoples negotiated an offset agreement for a culture centre as a fair exchange for a windfarm development. The resulting Tebrakunna Visitors Centre (TVC) is also sited at the location of Australia's first land rights agreement. Made in 1831 between the traw/wulwuy chief, Mannalargenna, and the colonial government, this agreement was never fulfilled and lay broken, dormant and forgotten. However, it was revitalised in 2015-2016 by traw/wulwuy peoples as the basis for constitutional recognition as Tasmania's First Peoples (Lee, 2015; Lee, 2016b).

Conservation of nature was not the priority for the creation of the Tebrakunna Visitors Centre. The focus on repairing relationships between Indigenous and other Tasmanians has positively influenced government and business policy through the sharing of cultural and historical knowledges stemming from the Tebrakunna Visitors Centre. In turn, conservation of tebrakunna country has resulted, including though protection of wildlife corridors for the reintroduction of healthy Tasmanian Devils. This reflects a deep desire by traw/wulwuy peoples to continue current cultural practices, recover others and have access to valued cultural and natural resources. Interestingly, the agreement has been used subsequently to assist in brokering the first joint management arrangement for a Tasmanian protected area, the Tasmanian Wilderness World Heritage Area, situated in the southwest of the state.

In summary, political and territorial recognition of the traw/wulwuy peoples has led, among many other positive trends, to the more equitable conservation of biodiversity in the form of one potential OECM (the Tebrakunna Visitors Centre's surrounding area) and an existing protected area (the Tasmanian Wilderness World Heritage Area). 
including through primary, secondary or ancillary forms of conservation and by Indigenous peoples and local communities. This is particularly important in the context of the latest Protected Planet Report (UNEPWCMC \& IUCN, 2016) and related research (Bingham et al., 2017) that underscore that protected areas are not yet meeting Target 11's terrestrial and marine targets, either at a global level or with regard to their coverage of ecoregions (UNEP-WCMC \& IUCN, 2016) and species (Butchart et al., 2015). The future equality of standing between protected areas and OECMs may have a number of beneficial effects, including the diversification of governance and management arrangements that are considered to contribute to qualitative and quantitative conservation targets at both international and (sub-) national levels. National agencies may thus be incentivised to better understand the worldviews, practices, responsibilities and rights of Indigenous peoples and local communities (Rights and Resources Initiative, 2015) and work with them to appropriately respect, support and report ICCAs that meet the definition of an OECM.

\section{Understanding and embracing holistic social- ecological systems}

The kinds of ICCAs that might also meet the definition of an OECM will likely have long-standing and relatively complex forms of 'ecosystem governance' (Vasseur et al., 2017), rooted in much broader cultural and spiritual beliefs and practices than those specifically focused on biodiversity. Individuals assessing potential OECMs will be prima facie interested in cultural and spiritual values and practices that lead to positive biodiversity outcomes (Dudley, 2008; IUCN-WCPA, 2017b). Yet for the reasons set out above, the social-ecological integrity of ICCAs could benefit from respect and support for Indigenous peoples' and local communities' broader cultural and spiritual systems, within which the more directly biodiversity-relevant aspects are nested. Actors involved in recognising ICCAs as OECMs must work outside the single issue silos to develop holistic, integrated and appropriate forms of support with the respective Indigenous peoples and local communities, subject to their free, prior and informed consent. It is hoped that funders also adopt progressive approaches to these needs, including through the Global Environment Facility under its proposed Operational Phase 7 impact programme on 'inclusive conservation' (Global Environment Facility, 2017). The alternative - provision of selective, externally-defined support - could have negative impacts, including on the governance and management of biodiversity.

\section{Upholding FPIC}

Extrapolating from existing international conservation policy, the external 'recognition' of an OECM must fully respect the rights of the Indigenous peoples and local communities (including their authorities and organisations responsible for such areas) and be based on their free, prior and informed consent (FPIC), and the governance of an OECM must reflect internationally-, regionally- and nationally-recognised human rights. This

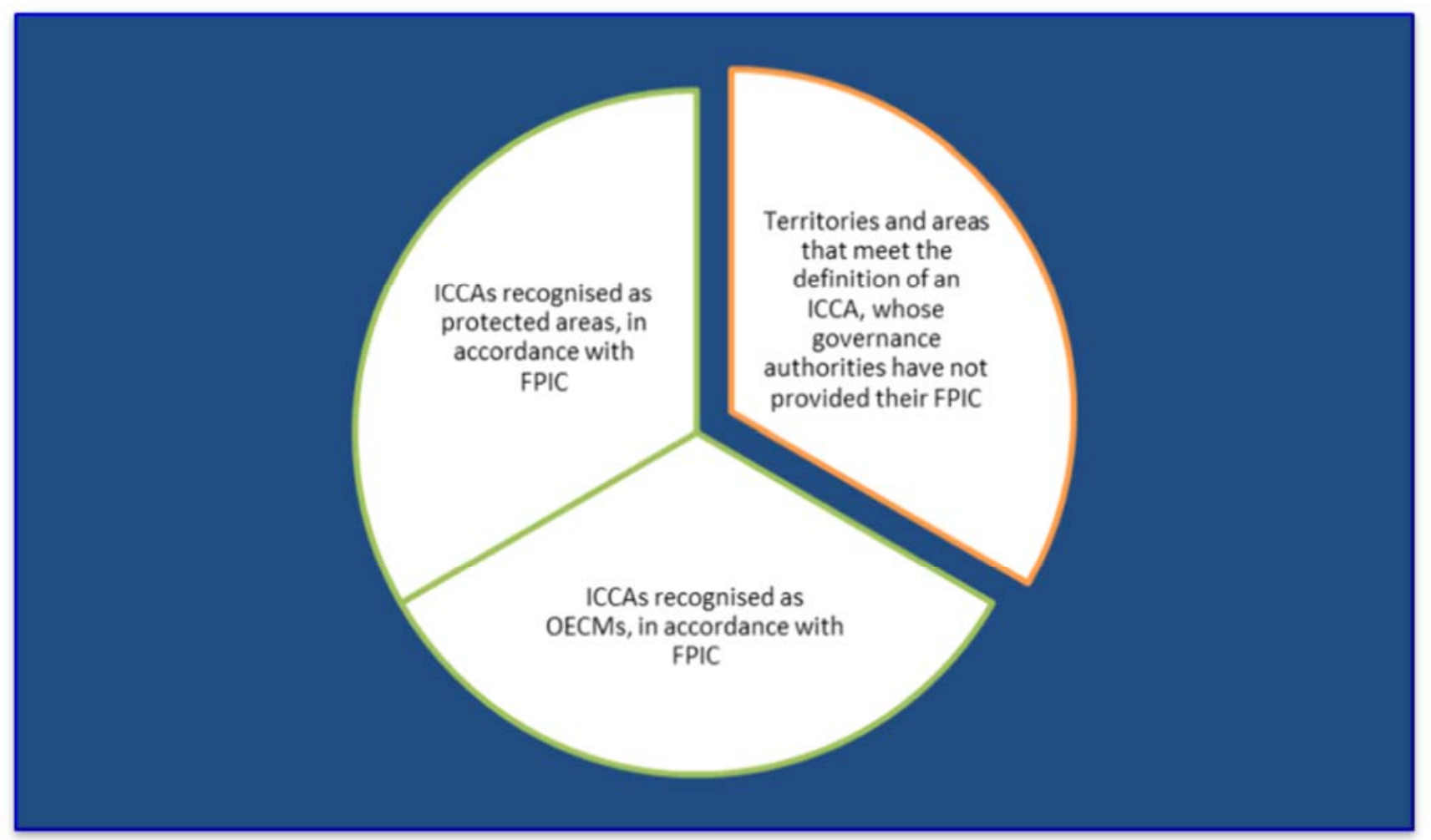

Figure 1: Recognition and reporting of ICCAs as protected areas or OECMs should be in accordance with the respective governance authorities' right to provide or withhold FPIC. The equal size of each segment is for illustration only. 
includes respecting ICCA governing authorities' decisions in two key situations. First, when the governing authorities of ICCAs that meet either the definition of a protected area or an OECM and who decide against the recognition of their territories or areas as either designation. Second, when the governing authorities of an ICCA that meets the definition of a protected area prefers the area to be recognised as an OECM. This may be an important option for some Indigenous peoples and local communities living in contexts where recognition of an area as a protected area might lead to negative consequences for the area or its governance, but where they still wish to have some recognition under the (sub-) national or international level framework for biodiversity conservation.

Upholding FPIC is critical to ensuring that injustices perpetrated against Indigenous peoples and local communities under protected area-related regulatory frameworks are not repeated in the context of OECMs (see Figure 1). This is especially important in the run up to 2020 (the deadline for CBD Parties to achieve the Strategic Plan and Aichi Targets), when state agencies will be under pressure to boost their area-based coverage to meet Target 11 and may be tempted to report ICCAs as OECMs without due process.

As a corollary, in order to recognise ICCAs as OECMs, states must develop dedicated legal and policy frameworks with the full and effective participation of Indigenous peoples and local communities. They are advised to ensure that such frameworks form constituent parts of broader legal and institutional frameworks that recognise and support the full spectrum of Indigenous peoples' and local communities' cultures, customary laws and institutions, rights and responsibilities (i.e., as above, not just the aspects associated directly with the conservation of biodiversity) (Rights and Resources Initiative, 2015). Thus, legal, policy and institutional reforms necessary to recognise OECMs at the (sub-) national level may provide an opportunity to advocate for other and possibly more systemic reforms to recognise and support Indigenous peoples' rights.

There is growing recognition in Canada at the Federal level that conservation by Indigenous peoples could contribute to Canada's Biodiversity Target 1 to protect or conserve $17 \%$ terrestrial and 10\% marine areas by 2020 (in line with Aichi Target 11). 9 Three ministries are actively engaged in the designation, recognition and management of protected and conserved areas: Environment and Climate Change Canada (ECCC), Indigenous and Northern Affairs Canada and Fisheries and Oceans Canada. Each uses different approaches to reach the targets and while the OECM-related work of each ministry and of several other Canadian bodies (MacKinnon et al., 2015 is notable. The example below focuses on the ECCC.

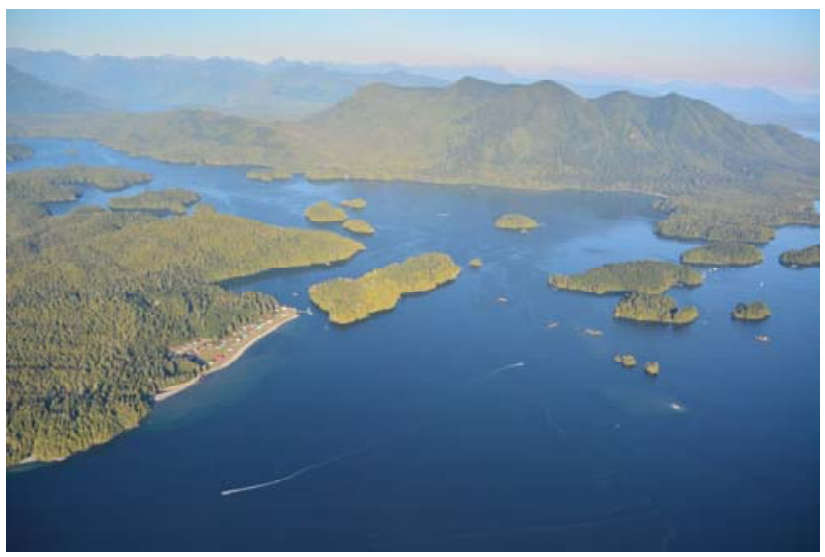

View towards Meares Island Tribal Park, governed by the Tla-o-qui-aht First Nation, with Opitsaht village in the foreground, British Colombia, Canada. (C) Jeremy Williams

\section{Example 2. Biodiversity Target 1, Canada:}

The ECCC has created a National Steering Committee and process called Pathway to Target 1. The Steering Committee has set up an Indigenous Protected and Conservation Areas (IPCA) Indigenous Circle of Experts (ICE) to help inform ECCC on how IPCAs will help Canada meet its Biodiversity Targets. In 2016, the ECCC Parks Agency's Vice -President said, "other effective area-based conservation measures and Indigenous protected areas could contribute significantly to achieving the $17 \%$ [terrestrial] target and a national network of conservation" and added that the Pathway to Target 1 process will "support a renewed nation-to-nation relationship with Indigenous peoples based on respect, co-operation, partnership, and the recognition of rights". ${ }^{10}$

However, members of the ICE feel that it would be inappropriate to set up IPCAs only as a way to meet Aichi Targets. The work ahead is seen as too critical to be rushed in order to meet 2020 targets. They have called for effective and meaningful solutions around jurisdictional issues, and have said that the government (at various levels) will need to be prepared to mobilise substantial and effective financial support for issues that currently stand in the way of being able to effectively recognise and support IPCAs. They believe that a deeper process of reconciliation will result in positive outcomes for both the Indigenous peoples and biodiversity. Exactly how this issue is resolved, and the way in which OECMs support the Pathway to Target 1's aims, will contribute to the discussion of a range of the issues raised in this paper. 


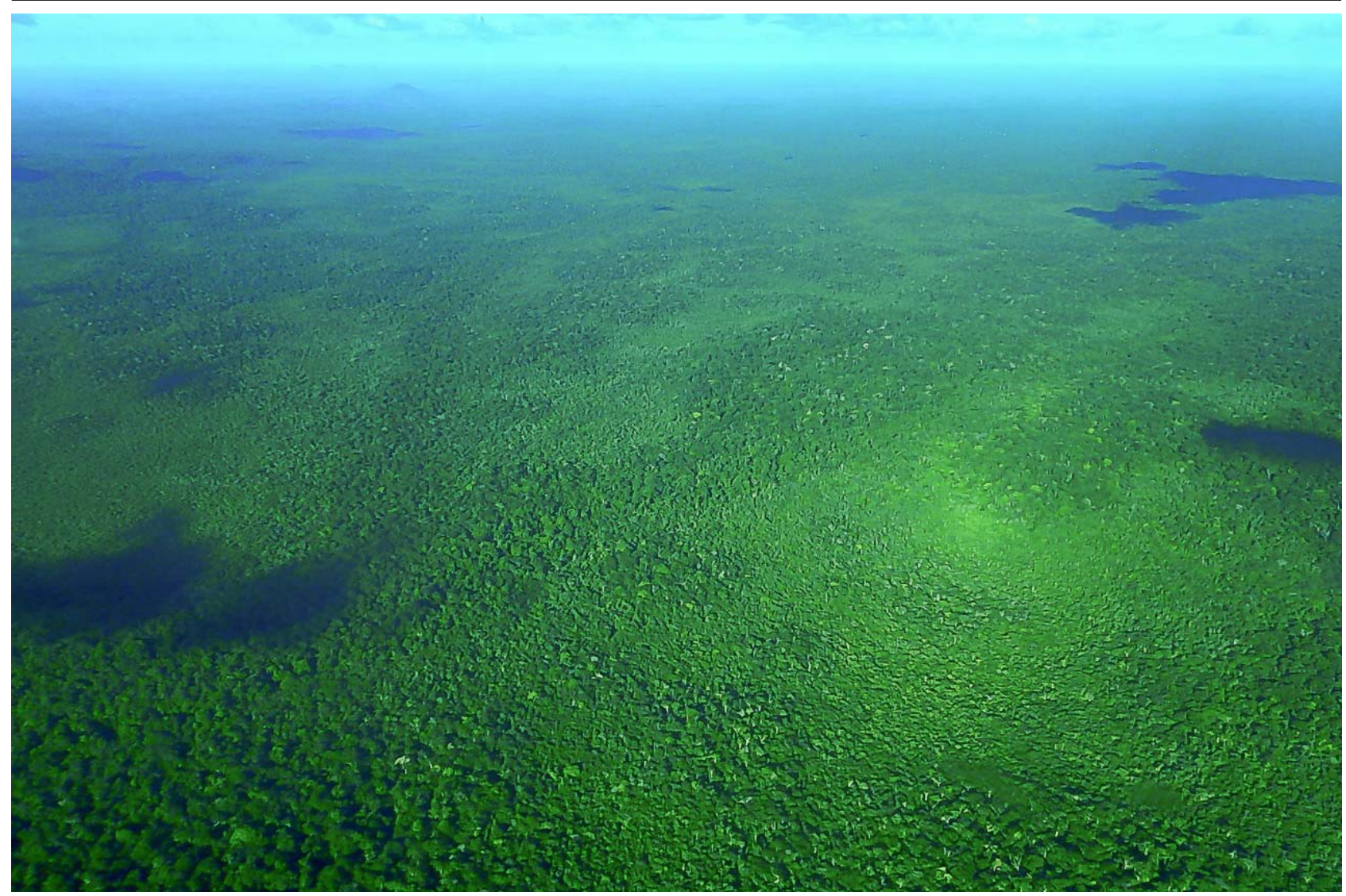

Indigenous territories in Vaupés, Colombia, Amazon Basin @ Ignacio Giraldo

\section{Addressing procedural challenges (and opportunities)}

One potential challenge is that governance authorities of potential OECMs will be called upon to demonstrate, among other things: the identification of the full range of key biodiversity attributes for which the site qualifies; effective and enduring in-situ conservation of biodiversity (Stolton \& Dudley, 2006; Geldmann et al., 2013; Nolte et al., 2013; Carranza et al., 2014; Watson et al., 2015); a direct causal link between the area's longterm management and the conservation outcomes; and effective means of control over activities that could impact biodiversity. These requirements raise conceptual and practical questions. Focusing on the practical aspects, and as reflected above, Indigenous peoples' and local communities' worldviews, knowledge, innovations and practices (CBD, 1992) have in many instances been denied, ignored and/or undermined by Western forms of science and conservation (IUCN, 2016c). Many Indigenous peoples and local communities have a deep understanding of their territories' and areas' biodiversity, natural resources and ecological functions and govern and manage them according to customary laws (Tobin, 2014), traditional ecological knowledge (Berkes, 1999) and spiritual and religious beliefs (Verschuuren et al., 2010). Yet they may also be at a significant disadvantage in attempting to demonstrate achievement of the above criteria using imposed languages and externallydeveloped methodologies. The concern is whether all
Indigenous peoples and local communities who want their territories and areas to be recognised as OECMs would be able to present, for example, the area's key biodiversity attributes and values in the format that may be required by national or international bodies. The potential for these criteria to be a procedural challenge underscores the importance of Indigenous peoples and local communities themselves - including custodians of ICCAs - being centrally involved in the development and implementation of (sub-)national OECM-related laws, policies, procedures and institutional arrangements.

Whatever the final formulation of these specific criteria and related procedures, there is an increased urgency to improve the collective understanding of Indigenous peoples' and community-based governance, management, monitoring and reporting systems, as well as the broader linkages between culture and biodiversity (Boedhihartono, 2017). In contrast, the absence of these conditions will likely discriminate against culturally specific, locally rooted approaches to the governance of ICCAs. Doing so will be challenging for many conservation actors, but may provide a significant opportunity to co-develop innovative approaches to the conservation of social-ecological landscapes and seascapes. Collective thinking and integrated solutions will be especially important as the effects of biodiversity loss and other anthropogenic phenomena such as climate change intensify. 
Example 3, Indigenous Reserves, Colombia: Some Indigenous territories in Colombia are recognised as Indigenous reserves under national law, implying also the recognition of the respective governing authorities' management approaches and related instruments such as 'planes de vida' (life plans). Currently 696 Indigenous reserves are recognised, which comprise 32 million hectares including at least 21 million hectares of forests. The recognition of these territories has not been without challenges. For example, issues around consideration of cultural practices and the ancestral concept of territory has resulted in cases of divided traditional areas and the creation of new structures of political representation that do not necessarily coincide with cultural realities (Rodriguez et al., 2014).

Notwithstanding these issues, Indigenous peoples are working to maintain their traditional knowledge and vision of their territories, including through this framework. In the Colombian Amazon, for example, ethnic groups such as Yucunas and Matapis, are working with NGOs such as Tropenbos Colombia on the documentation of their knowledge of their territories and management to develop ancestral maps in order to avoid losing practices that are based mainly on shamanic concepts, including traditional approaches to forest management, and which demonstrate how indigenous people contribute to the conservation of tropical rainforests (Rodriguez et al., 2014; Matapí \& Yucuna, 2012). Such cases illustrate the importance of recognition of community-based governance and traditional knowledge systems based on and permitting existence in equilibrium with nature.

\section{CONCLUSIONS AND RECOMMENDATIONS}

Protected areas are one important means by which many ICCAs can gain greater recognition for their contributions to conservation, subject to important caveats. The ongoing process of international and (sub-) national reform of protected areas law and policy including recognising Indigenous peoples' and communities' rights and governance capacities - has the potential to increase the number of ICCAs whose governing authorities propose or consent to such recognition.

In parallel, mindful crafting of international and (sub-) national guidelines, laws and institutional arrangements on OECMs and their rights-based implementation may represent an important new inflection point in the evolution of conservation policy and practice. It may also lead to the improved recognition of conservation contributions of Indigenous peoples and local communities and increase support for the biodiversity that exists - whether thriving or under threat - outside protected areas. Recognition of particular ICCAs as OECMs may also provide increased security and visibility and lead to greater recognition and support for the territory or area, though this is subject to government agencies and private actors providing 'teeth' to this designation. A progressive approach to OECMs may also lead, in some instances, to a form of 'restorative ecology', whereby recognising and supporting individual ICCAs as OECMs catalyses a healing and transformative process for all parties involved.

However, such transformative processes and outcomes are by no means guaranteed. OECM-related frameworks could instead further entrench dichotomous approaches to 'science', 'culture' and 'nature' that deny the value of the interconnectedness of Indigenous peoples' and local communities' worldviews, knowledges and forms of governance and management. Governments and other agencies could focus their support too narrowly on biodiversity-related elements of Indigenous peoples' and local communities' cultures and governance structures. States could develop national OECM frameworks without the full and effective participation of Indigenous peoples and local communities. Government agencies could rush to meet their international commitments under Target 11 in ways that do not uphold the FPIC of Indigenous peoples and local communities. OECM-related recognition and reporting procedures could be perceived by Indigenous peoples and local communities as discriminating against community governance authorities that are less equipped to comply with them. More broadly, dedicated processes are required to resolve continuing issues with ICCAs overlapped by protected areas and may also be required if ICCAs are overlapped by OECMs without their FPIC. Under conditions such as these, the governance authorities of ICCAs may at best be disinterested in engaging with the framework. At worst, OECMs may be used - whether inadvertently or not - to further undermine the socialecological integrity of ICCAs.

In making the case for the development of technical guidelines on OECMs, Jonas et al. (2014) invoked the Inaugural Poem by Maya Angelou to make the point that international law and policy can, under the right circumstances, offer "space to place new steps of change" (Angelou, 1993). In this context, the advent of OECMs provides a new means of recognising - among other things - very old forms of conservation; namely, those occurring as the outcome of Indigenous peoples' and local communities' relationships with their 
territories and areas. An increase in the appropriate recognition of these previously under-appreciated systems will have many potential benefits for their governance authorities and broader communities, and the biodiversity within them. The question is, in which direction will things develop under this 'new' initiative?

Finally, two practical recommendations are as follows. First, to ensure that the unique and valuable characteristics of ICCAs are fully considered in the implementation of the IUCN Guidelines on OECMs, it is proposed that the WCPA undertake a process immediately following the publication of the guidelines on OECMs, in partnership with Indigenous peoples, local communities and relevant support organisations, to develop supplementary guidelines (for example, Day et al., 2012) on ICCAs and OECMs. This will provide an opportunity to co-develop a deeper understanding of the nuances of how the guidelines apply to ICCAs and to set out clear and tailored guidance for a range of rightsholders and stakeholders.

Second, there is a notable recent increase in the number of references to 'conserved areas' without specifying whether it is as shorthand for ICCAs, OECMs or something else. For example, the Promise of Sydney and the New Social Compact both make extensive reference to 'protected and conserved areas' (IUCN, 2014a, 2014b), and the term is also found in the names of the IUCN 'Green List of Protected and Conserved Areas' and the WCPA 'Specialist Group on the Governance of Protected and Conserved Areas'. It is therefore recommended that a wide range of interested parties discuss the pros and cons of referring to 'OECMs' as 'conserved areas' to promote a common language across policy makers and practitioners, including in the context of the CBD and IUCN.

\section{ENDNOTES}

${ }^{1}$ OECMs were referenced in eight $\mathrm{CBD}$ decisions, namely: Progress towards the achievement of Aichi Biodiversity Targets 11 and 12 (Decision XIII/2); Strategic actions to enhance implementation of the Convention and the Strategic Plan for Biodiversity 2011-2020 and the achievement of the Aichi Biodiversity Targets, including the mainstreaming of biodiversity within and across sectors (Decision XIII/3); Biodiversity and climate change (Decision XIII/4); Marine spatial planning and training initiatives (Decision XIII/9); Voluntary specific workplan on biodiversity in cold water areas within the jurisdictional scope of the Convention (Decision XIII/11); Resource mobilisation (Decision XIII/20); Capacity-building, technical and scientific cooperation, technology transfer and the clearing-house mechanism (Decision XIII/23); Indicators for the Strategic Plan for Biodiversity 2011-2020 and the Aichi Biodiversity Targets (Decision XIII/28).
2 IUCN-WCPA (2015) For further information on the Task Force, see: https://www.iucn.org/theme/protected-areas/ wcpa/what-we-do/other-effective-area-based-conservationmeasures-oecms

${ }^{3}$ The IUCN definition of a protected area is: "A clearly defined geographical space, recognised, dedicated and managed, through legal or other effective means, to achieve the longterm conservation of nature with associated ecosystem services and cultural values" (Dudley, 2008).

${ }^{4}$ The examples assume that the governance authorities have provided free, prior and informed consent to being recognized as such.

${ }^{5}$ Some protected areas, such as those that are proposed rather than designated, have been removed from these figures. For more information on how statistics are calculated using the WDPA, consult https://protectedplanet.net/c/ calculating-protected-area-coverage

${ }^{6}$ Local governance arrangements are often more complex than a term such as 'governing authority' can convey. The paper acknowledges these local realities, but uses the simplified 'governing authority/authorities' to retain the focus on the other core arguments. More discussion of the governance-related issues relevant to ICCAs and OECMs is warranted.

${ }^{7}$ www.padddtracker.org

${ }^{8}$ Tasmanian Aboriginal language is written in italics and capital letters are only used for peoples' names.

${ }^{9}$ See: http://www.conservation2020canada.ca/. The example was written by Eli Enns, who is a member of the Indigenous Circle of Experts.

${ }^{10} 4$ October 2016 meeting of the Standing Committee on Environment and Sustainable Development transcript: https://www.ourcommons.ca/DocumentViewer/en/42-1/ ENVI/meeting-27/minutes

${ }^{11}$ Proving the area's management is a long-term measure may be difficult for some Indigenous peoples and local communities in the absence of written management plans. A track record of the way an area has been managed should be one way in which this criterion can be met. Using case studies from a range of ICCAs and locally managed marine areas (LMMAs) to better understand and articulate the complex relationships between different types of measures, livelihoods and biodiversity will likely improve the guidance and its implementation in the context of a range of areas governed by Indigenous peoples and local communities.

12 'Restorative justice' is a system of criminal justice that focuses on the rehabilitation of offenders through reconciliation with victims and the community at large. In the same vein, 'restorative ecology' may be one way to describe forms of ecology that encapsulate forms of restitution and reconciliation between various rights-holders and stakeholders. 


\section{ACKNOWLEDGEMENTS}

The authors gratefully acknowledge the work of the Task Force on OECMs and the additional individuals who have invested time in providing inputs and case studies. We also thank the following individuals who have provided inputs to this paper: Heather Bingham, Grazia Borrini-Feyerabend, Nigel Dudley, Stephen Garnett, Brent Mitchell, Stan Stevens and Bas Verschuuren, as well as to the editors at PARKS and two anonymous reviewers.

\section{ABOUT THE AUTHORS}

Harry Jonas, based in Sabah (Malaysia), is an international environmental and human rights lawyer, co -founded Natural Justice and supports the ICCA Consortium and Forever Sabah. Harry co-chairs the IUCN World Commission on Protected Areas' Task Force on Other Effective Area-based Conservation Measures. His publications include: a novel, Tyranny of the Masses (www.tyranny-of-the-masses.com), The Right to Responsibility, The Living Convention and Conservation Standards. He is an Ashoka Fellow.

Emma Lee is a trawlwulway woman of Tasmania and Research Fellow at the Centre for Marine Socioecology, University of Tasmania. She has written extensively on protected areas and Aboriginal people and has had a senior role in developing the first joint management agreement for Aboriginal people in the Tasmanian Wilderness World Heritage Area. Emma is a member of the Australian World Heritage Indigenous Network (AWHIN) and an Honorary Member of the ICCA Consortium.

Holly Jonas, based in Sabah (Malaysia), is the International Policy Coordinator for the ICCA Consortium and works with other non-profit organisations in Sabah and internationally to support Indigenous peoples' and local communities' territories and ways of life. Her background is in international environmental and human rights law, zoology and cultural anthropology and she is a member of several volunteer networks and working groups, including in IUCN. She has co-authored and edited a number of articles, reports and volumes on issues related to law, conservation and human rights.

Clara Matallana-Tobon, based in Bogota (Colombia), is an ecologist from Colombia, with a Master's degree on Biological Conservation from California State University. She is currently the leader of the protected areas and other conservation measures research team of the Humboldt Institute, the official organisation in Colombia for biodiversity research. She works with regional and national authorities in order to enhance the protected areas networks, setting priorities for new protected areas, reviewing proposals for the establishment of regional protected areas, and nomination of Important Bird Areas. She is a member of the Green List reference group for Colombia.

Kim Sander Wright, based in British Columbia (Canada), has spent 20 years working on multi-cultural and multi-stakeholder processes to ensure adequate representation of all rights holders and stakeholders in the governance of land and coastal environments. She studied natural environmental sciences and international human conflict and has been involved as an advisor and facilitator in many land and marine use planning processes with Indigenous rights holders. She is currently the Senior Marine Planning Strategist at the David Suzuki Foundation and the Strategic Advisor on Marine, Coastal and Island Environments to the ICCA Consortium.

Fred Nelson, based in Vermont (USA), is the founder and Executive Director of Maliasili Initiatives. He has worked on natural resource management and sustainable development in East Africa since 1998, serving as both director and board member of leading conservation organisations in Tanzania, and has worked with a wide range of groups to design and facilitate community-based conservation initiatives with local communities in northern Tanzania. He has been published in journals such as Development and Change, Conservation Biology, Oryx, and Biodiversity \& Conservation, and is the editor of: Community Rights, Conservation and Contested Land: The Politics of Natural Resource Governance in Africa, Earthscan, 2010.

Eli Enns, based in British Columbia (Canada) is a Nuuchah-nulth Canadian political scientist focused on Constitutional Law, International Dispute Resolution and Ecological Governance. He is the co-founder of the Ha'uukmin Tribal Park in Clayoquot Sound on the west coast of Vancouver Island, holds a range of posts, including: Indigenous Circle of Experts (as part of the Pathway to Target 1), Member; Canadian Commission for UNESCO Man and the Biosphere National Committee, Committee Member; and Plenty Canada, Nation Building Program Director. With Ecotrust Canada, Eli helped develop an Indigenous Watershed Management Area Program offering services to First Nations across Canada. Eli was a recipient of the 2oth Anniversary Canadian Model Forest Achievement Award in 2012.

\section{REFERENCES}

Adams, W. and Mulligan M. (eds.) (2004). Decolonizing Nature: Strategies for Conservation in a Post-colonial Era. London, UK: Earthscan. doi.org/10.4324/9781849770927

AIPP (2013). Research on the Roles and Contributions of Indigenous Women in Sustainable Forest Management in Mekong Countries/Asia. Chiang Mai, Thailand: AIPP. 
Angelou, M. (1993). On the Pulse of Morning. http:// www.nytimes.com/1993/01/21/us/the-inaugurationmaya-angelou-on-the-pulse-of-morning.html.

Bennett, N., Govan, H. and Satterfield, T. (2015). 'Ocean grabbing.' Marine Policy 57: 61-68. doi.org/10.1016/ j.marpol.2015.03.026

Berkes, F. (1999). Sacred Ecology: Traditional Ecological Knowledge and Resource Management, 2nd ed. Routledge.

Berkes, F., Colding, J. and Folke, C. (eds.) (2003). Navigating Social-ecological Systems: Building Resilience for Complexity and Change. Cambridge, UK: Cambridge University Press. doi.org/10.1017/cbo9780511541957

Bhatt, S., Pathak, N., Kothari, A. and Balasinorwala, T. (eds.) (2012). Community Conserved Areas in South Asia: Case studies and Analyses from Bangladesh, India, Nepal, Pakistan, and Sri Lanka. Pune, India: Kalpavriksh.

Bingham, H., Fitzsimons, J., Redford, K., Mitchell, B., BezauryCreel, J. and Cumming T. (2017). 'Privately Protected Areas: Advances and Challenges in Guidance, Policy and Documentation.' PARKS 23(1). doi.org/10.2305/ iucn.ch.2017.parks-23-1hb.en

Boedhihartono, A. (2017). 'Can Community Forests be Compatible with Biodiversity in Indonesia?' Land 6:21. doi.org/10.3390/land6010021

Borrini-Feyerabend, G. (ed.) (2010). Strengthening What Works: Recognising and Supporting the Conservation Achievements of Indigenous Peoples \& Local Communities. IUCN-CEESP Briefing Note No. 10. Tehran: CENESTA.

Borrini-Feyerabend, G., Dudley, N., Jaeger, T., Lassen, B., Pathak Broome, N., Phillips, A. and Sandwith, T. (2013). Governance of Protected Areas: From understanding to action. Best Practice Protected Area Guidelines Series No. 20, Gland, Switzerland: IUCN. p. 5.

Borrini-Feyerabend, G., Bueno, P., Hay-Edie, T., Lang, B., Rastogi, A. and Sandwith, T. (2014). A Primer on Governance for Protected and Conserved Areas, Stream on Enhancing Diversity and Quality of Governance. IUCN World Parks Congress. Gland, Switzerland: IUCN.

Borrini-Feyerabend, G. (2016). 'Mothers or lesser sisters? The strange case of "conserved areas"'. CBD Square Brackets. Montreal, Canada: CBD.

Bray, D., Duran, E., Ramos, E., Mas, J-F, Velazquez, A., McNab, R., Barry, D., and Radachowsky, J. (2008). 'Tropical deforestation, community forests, and protected areas in the Maya Forest'. Ecology and Society 13(2): 56. doi.org/10.5751/es-02593-130256

Brockington, D. and Igoe, J. (2006). 'Eviction for Conservation: A Global Overview'. Conservation and Society 4:424-470.

Brown, J. and Kothari, A. (2011). 'Traditional Agricultural Landscapes and Community Conserved Areas: An Overview.' 22(2) Management of Environmental Quality: An International Journal 139. doi.org/10.1108/14777831111113347

Burnham, P. (2000). Indian Country, God's Country: Native Americans and the National Parks. Washington, DC: Island Press. doi.org/10.5860/choice.38-1733

Butchart, S., Clarke, M., Smith, R., Sykes, R., Scharlemann, J., Harfoot, M., Buchanan, G., Angulo, A., Balmford, A., Bertzky, B., Brooks, T., Carpenter, K., Comeros-Raynal, M., Cornell, J., Ficetola, G., Fishpool, L., Fuller, R., Geldmann, J., Harwell, H., Hilton-Taylor, C., Hoffmann, M., Joolia, A., Joppa, L., Kingston, N., May, I., Milam, A., Polidoro, B., Ralph, G., Richman, N., Rondinini, C., Segan, D., Skolnik, B., Spalding, M., Stuart, S., Symes, A., Taylor, J., Visconti, P., Watson, J., Wood, L. and Burgess, N. (2015). 'Shortfalls and Solutions for Meeting National and Global Conservation Area Targets.' Conservation Letters, September/October 2015, 8(5), 329-337. doi.org/10.1111/conl.12158

CAPAD (2014). Collaborative Australian Protected Area Database, Department of the Environment, Australian Government, viewed 23 March 2016.

Carranza, T., Manica, A., Kapos, V. and Balmford, A. (2014). 'Mismatches between conservation outcomes and management evaluation in protected areas: A case study in the Brazilian Cerrado', Biological Conservation, 173. doi.org/10.1016/j.biocon.2014.03.004

CBD (1992). Convention on Biological Diversity. Secretariat of the CBD: Montreal.

CBD (2010). 'Decision X/2: Strategic Plan for Biodiversity 2011 -2020.' Adopted by the Conference of the Parties to the Convention on Biological Diversity at its Tenth Meeting.

CBD (2013). Item 3 of the Provisional Agenda of the $17^{\text {th }}$ Meeting of the Subsidiary Body on Scientific, Technical and Technological Advice, 'The Identification of Scientific and Technical Needs for the Attainment of the Targets Under Strategic Goal C of the Strategic Plan for Biodiversity 2011-2020' UNEP/CBD/SBSTTA/17/2/Add.3.

CBD (2014). Report of the $17^{\text {th }}$ Meeting of the Subsidiary Body on Scientific, Technical and Technological Advice on the Work of its Seventeenth Meeting. UNEP/CBD/COP/12/2.

CBD (2016). Progress in the implementation of the Convention and the Strategic Plan for Biodiversity 20112020 and towards the achievement of the Aichi Biodiversity Targets (CBD/COP/DEC/XIII/2).Ceballos, G., Ehrlich, P. and Dirzo, R. (2017). 'Biological annihilation via the ongoing sixth mass extinction signaled by vertebrate population losses and declines.' Proceedings of the National Academy of Sciences. PNAS 2017. doi.org/10.1073/pnas.1704949114

CIPTA \& WCS (Tacana Indigenous People's Council and Wildlife Conservation Society) (2013). Deforestation Scenarios in the Greater Madidi-Tambopata Landscape. Bogota: WCS-Bolivia.

Coalition Against Land Grabbing (2015). The Repression of Defenders of Commons and ICCAs in Caraga Region, Mindanao-Philippines. Philippines: Coalition Against Land Grabbing.

Cohen, G.A. (1978). Karl Marx's Theory of History: a Defence. Princeton University Press: Princeton. doi.org/10.1093/ oxfordhb/9780198717133.013.57

Colchester, M. (2003). Salvaging Nature: Indigenous Peoples, Protected Areas and Biodiversity Conservation. UK: World Rainforest Movement and Forest Peoples Programme.

Day, J., Dudley, N., Hocking, M., Holmes, G., Lafolley, D., Stolton, S., and Wells, S. (2012). Guidelines for Applying the IUCN Protected Areas Management Categories to Marine Protected Areas. Gland, Switzerland: IUCN.

Diz, D., Johnson, D., Riddell, M., Rees, S., Battle, J., Gjerde K., Hennige, S. and Roberts, M.R., (2017). 'Mainstreaming marine biodiversity into the SDGs: The role of other effective area-based conservation measures (SDG 14.5)'. Marine Policy. doi.org/10.1016/j.marpol.2017.08.019

Dowie, M. (2009). Conservation Refugees: The Hundred-year Conflict between Global Conservation and Native Peoples. Massachusetts: MIT Press. doi.org/10.1111/j.15481433.2010.01239_5.x

Dudley, N. (ed.) (2008). Guidelines for Applying Protected Area Management Categories. Gland, Switzerland: IUCN. 
Folke, C., Hahn, T., Olsson, P. and Norberg, J. (2005). 'Adaptive Governance of Social-ecological Systems.' Annual Review of Environment and Resources 30: 441.

Geldmann, J., Barnes, M., Coad, L., Craigie, I.D., Hockings, M. and Burgess, N.D. (2013). 'Effectiveness of terrestrial protected areas in reducing habitat loss and population declines' Biological Conservation 161: 230-238. doi.org/10.1016/j.biocon.2013.02.018

Gibbs, L.M. (2006). 'Valuing water: variability and the Lake Eyre Basin, central Australia', Australian Geographer, 37 (1), 73-85. doi.org/10.1080/00049180500511988

Global Environment Facility (2017). Report of the First Meeting for the Seventh Replenishment of the GEF Trust Fund (GEF/R.7/02). Washington, DC: Global Environment Facility.

Global Witness (2017). Defenders of the Earth. London, UK: Global Witness.

Greiber, T., Janki, M., Orellana, M., Savaresi, A. and Shelton, D. (2009). Conservation with Justice. A Rights-based Approach. Gland, Switzerland: IUCN. doi.org/10.2305/ iucn.ch.2009.eplp.71.en

Hayes, T. and Ostrom, E. (2005). 'Conserving the World's Forests: Are Protected Areas the Only Way?' Indiana Law Review 38: 595.

Healey, G. and Tagak, A. (2014). 'PILIRIQATIGIINNIQ "Working in a collaborative way for the common good": A perspective on the space where health research methodology and Inuit epistemology come together', International Journal of Critical Indigenous Studies, 7 (1): 1-14.

IDMC (Internal Displacement Monitoring Centre). Global Report on Internal Displacement (2017). Geneva: IDMC.

Indian Law Resource Centre and IUCN (2015). Conservation and Indigenous Peoples in Mesoamerica: A Guide. Gland: Indian Law Resource Centre and IUCN-CEESP.?

International Work Group for Indigenous Affairs (2017). Hansen K.B., Jepsen K., P.L. Jacquelin (eds.). The Indigenous World 2017. Netherlands: IWGIA.

IUCN (2003). The Durban Accord: Our Global Commitment for People and Earth's Protected Areas. Gland: IUCN.

IUCN (2012a). 'Facilitating conservation through the establishment of protected areas as a basis for achieving Target 11 of the Strategic Plan for Biodiversity 2011-2020' (WCC-2012-Res-035-EN) in IUCN, Resolutions and Recommendations. Gland, Switzerland: IUCN.

IUCN (2012b). 'Position Paper on Protected areas', Agenda Item 13.4. Submitted to the eleventh meeting of the Conference of the Parties to the Convention on Biological Diversity.

IUCN (2014a). Promise of Sydney. Gland, Switzerland: IUCN.

IUCN (2014b). New Social Compact. Gland, Switzerland: IUCN.

IUCN-WCPA (2015). Jonas H. and K. MacKinnon, Discussion Paper on OECMs: framing the issues. Gland, Switzerland: IUCN-WCPA.

IUCN-WCPA (2016a). Jonas H and K. Mackinnon (eds.) CoChairs' Reports of the First Meeting of the IUCN-WCPA Task Force on Other Effective Area-based Conservation Measures. Gland, Switzerland: IUCN-WCPA.

IUCN-WCPA 2016b. Jonas H. and K. MacKinnon (eds.). Advancing Guidance on Other Effective Area-based Conservation Measures: Report of the Second Meeting of the IUCN-WCPA Task Force on Other Effective Area-based Conservation Measures. Gland, Switzerland and Bonn, Germany: IUCN and Bundesamt für Naturschutz.
IUCN-WCPA (2016c). Guidance for Recognizing and Reporting of Other Effective Area-based Conservation Measures under Target 11: Consultation Document. Gland, Switzerland: IUCN.

IUCN-WCPA (2017a). (Draft) Guidelines for Recognizing and Reporting Other Effective Area-based Conservation Measures: First Version. Gland, Switzerland: IUCN.

IUCN-WCPA (2017b). Jonas H. and K. MacKinnon (eds.) Using Case Studies to Enhance Guidance on Other Effective Areabased Conservation Measures: Report of the Third Meeting of the IUCN-WCPA Task Force on Other Effective Area-based Conservation Measures. Gland, Switzerland: IUCN.

Johnson, J.J., Cant, G., Howitt, R. and Peters, E. (2007). 'Guest editorial. Creating anti-colonial geographies: embracing Indigenous peoples' knowledge and rights', Geographical Research 45(2), 117-120.

Johnson, J.T. and Murton B. (2007). 'Re/placing native science: Indigenous voices in contemporary constructions of nature', Geographical Research 45 (2), 121-129. doi.org/10.1111/j.1745-5871.2007.00442.x

Jonas, H.C. (2016). 'Indigenous peoples' and community conserved territories and areas (ICCAs): evolution in international biodiversity law', in Morgera E. and J. Razzaque (eds.) Elgar Encyclopedia of Environmental Law: Biodiversity and Nature Protection Law. UK: Elgar. doi.org/10.4337/9781783474257.iii.10

Jonas, H. D. (2012). Legal and Institutional Aspects of Recognizing and Supporting Conservation by Indigenous Peoples and Local Communities: An Analysis of International Law, National Legislation, Judgements and Institutions as they Interrelate with Territories and Areas Conserved by Indigenous Peoples and Local Communities. Bangalore and Pune, India: Natural Justice and Kalpavriksh.

Jonas, H.D., Barbuto, V., Jonas, H.C., Kothari, A. and Nelson F. (2014). 'New Steps of Change: Looking Beyond Protected Areas to Consider Other Effective Area-based Conservation Measures.' PARKS 20.2. Gland, Switzerland: IUCN. doi.org/10.2305/iucn.ch.2014.parks-20-2.hdj.en

Juffe-Bignoli, D., Harrison, I., Butchart, S., Flitcroft, R., Virgilio, H., Jonas, H., Lucasiewicz, A., Thieme, M., Turak, E., Bingham, H., Dalton, J., Darwall, W., Deguignet, M., Dudley, N., Gardner, R., Higgins, J., Kumar, R., Linke, S., Milton, G.R., Pittock, J., Smith, K., and van Soesbergen, A. (2016). 'Achieving Aichi Biodiversity Target 11 to Improve the Performance of Protected Areas and Conserve Freshwater Biodiversity.' Aquatic Conservation. 26 (Suppl. 1): 133-151. doi.org/10.1002/aqc.2638

Kashwan, P. (2013). 'The Politics of Rights-based Approaches in Conservation' (2013). Land Use Policy 31: 613. doi.org/10.1016/j.landusepol.2012.09.009

Knox, J. (2017) Report of the Special Rapporteur on the issue of human rights obligations relating to the enjoyment of a safe, clean, healthy and sustainable environment (A) $\mathrm{HRC} / 34 / 49$ ). Submitted to the $34^{\text {th }}$ Session of the Human Rights Council.

Kothari, A., Pathak, N. and Vania, F. (2000). Where Communities Care: Community Based Wildlife and Ecosystem Management in South Asia. Pune, India: Kalpavriksh and IIED.?

Kothari, A., Corrigan C., Jonas H.D., Neumann A. and Shrumm H. (eds.) (2012). Recognising and Supporting Territories and Areas Conserved by Indigenous Peoples and Local Communities: Global Overview and National Case Studies 
(CBD Technical Series No. 64, Secretariat of the Convention on Biological Diversity, ICCA Consortium . Pune, India and Montreal, Canada: Kalpavriksh and Natural Justice.

Kothari, A. and Neumann A. (2014). ICCAs and Aichi Targets: The Contribution of Indigenous Peoples' and Local Community Conserved Territories and Areas to the Strategic Plan for Biodiversity 2011-20. Policy Brief of the ICCA Consortium, no. 1, co-produced with CBD Alliance, Kalpavriksh and CENESTA and in collaboration with the IUCN Global Protected Areas Programme.Laffoley, D., Dudley, N., Jonas, H.D., MacKinnon, D., MacKinnon, K., Hockings, M. and Woodley S. (2017). 'An introduction to "other effective area-based conservation measures" under Aichi Target 11 of the Convention on Biological Diversity: origin, interpretation and some emerging ocean issues.' Aquatic Conservation: Marine and Freshwater Ecosystems. 1-8 doi.org/10.1002/aqc.2783

Lee, E. (2015), 'Talking Point: honouring history's promise', The Mercury, 31 October, viewed 25 June 2017, < http:// www.themercury.com.au/news/opinion/honouringhistorys-promise/newsstory/914dfdf14ba46c9f58d6b358447d0968>.

Lee, E. (2016a). 'Protected areas, country and value: the nature-culture tyranny of the IUCN's protected area guidelines for Indigenous Australians', Antipode, 48 (2), 355-374. doi.org/10.1111/anti.12180

Lee, E. (2016b). 'Talking Point: wilderness plan benchmark to renew relations', The Mercury, 8 January, viewed 24 June 2017, < http://www.themercury.com.au/news/opinion/ talking-point-wilderness-plan-benchmark-to-renewrelations/news-story/ b6b316bce3756d2d064760cf36d82110>.

Lopoukhine, N. and de Souza Dias, B. F. (2012). 'Editorial: What does Target 11 really mean?' PARKS 18(1): 5.

Lovgren, S., (2003). 'Map Links Healthier Ecosystems, Indigenous Peoples'. National Geographic News. Available online at: http://bit.ly/1kENKxB.

MacKinnon, D., Lemieux, C., Beazley, K., 国Woodley, S., Helie, R., Perron, J., Elliott, J., Haas, C., Langlois, J., Lazaruk, H., Beechey, T. and Gray, P. (2015). 'Canada and Aichi Biodiversity Target 11: understanding "other effective area-based conservation measures"]in the context of the broader target.' Biodiversity Conservation 24. doi.org/10.1007/s10531-015-1018-1

Matapi, U. and Yucuna, R. (2012). Cartografía ancestral yucuna-matapí: conocimiento y manejo tradicional del territorio. Proyecto Cartografía Cultural del Noreste mazónico. Ministerio de Cultura, Patrimonio Natural. Bogotá, Colombia: Fondo para la Biodiversidad y Áreas Protegidas en alianza con Tropenbos Internacional.

Minority Rights Group (2012). State of the World's Minorities and Indigenous Peoples: Focus on Land Rights and Natural Resources. London, UK: Minority Rights Group.

Molnar, A., Scherr, S. and Khare, A. (2004). Who conserves the world's forests: community driven strategies to protect forests and respect rights. Washington, DC, USA: Forest Trends and Eco-agriculture Partners.

Morel, C. (2010). 'Conservation and Indigenous Peoples' Rights: Must One Necessarily Come at the Expense of the Other?' in Shrumm $\mathrm{H}$ (ed.) Exploring the Right to Diversity in Conservation Law, Policy, and Practice, (pp. 174-180) Policy Matters 17, Malaysia: IUCN.

Nagendra, H. (2008). 'Do Parks Work? Impact of Protected Areas on Land Cover Clearing' AMBIO: A Journal of the
Human Environment 37(5): 330.? doi.org/10.1579/06-r184.1

Nelson, A. and Chomitz K.M. (2011). 'Effectiveness of Strict vs. Multiple Use Protected Areas in Reducing Tropical Forest Fires: A Global Analysis Using Matching Methods'. PLoS ONE, 6(8): e22722. doi:10.1371/journal.pone.0022722. doi.org/10.1371/journal.pone.0022722

Nepstad, D., Schwartzman, S., Bamberger, B., Santilli, M., Ray, D., Schlesinger, P., Lefebvre, P., Alencar, A., Prinz, E., Fiske, G. and Rolla, A. (2006). 'Inhibition of Amazon Deforestation and Fire by Parks and Indigenous Lands'. Conservation Biology, 20(1): 65-73. doi.org/10.1111/ j.1523-1739.2006.00351.x

Nolte, C., Agrawal, A., Silvius, K.M., and Soares-Filho, B.S. (2013). 'Governance Regime and Location Influence Avoided Deforestation Success of Protected Areas in the Brazilian Amazon'. Proceedings of the National Academy of Sciences, 110(13): 4956-4961. doi.org/10.1073/ pnas. 1214786110

Ostrom, E. (1990). Governing the Commons: The Evolution of Institutions for Collective Action. Cambridge, UK: Cambridge University Press. doi.org/10.1017/ cbo9780511807763.002

Ostrom, E. (2000). 'Collective Action and the Evolution of Social Norms.' The Journal of Economic Perspectives 14(3): 137. doi.org/10.1080/19390459.2014.935173

Pathak, N. (ed.) (2009). Community Conserved Areas in IndiaA Directory. Pune, India: Kalpavriksh. [?Phillips, A. (2004). 'Turning Ideas on their Head: The New Paradigm for Protected Areas.' Environmental History, 9(1) 173.

Phyälä, A., Orozco A., and Counsell, S. (2016). Protected Areas in the Congo Basin: Failing both People and Biodiversity? London, UK: Rainforest Foundation UK.

Poirier, R. and Ostergren, D. (2002). 'Evicting People from Nature: Indigenous Land Rights and National Parks in Australia, Russia, and United States'. Natural Resources Journal 42 (2), Spring 2002.

Porter-Bolland, L., Ellis, E.A., Guariguata, M.R., Ruiz-Mallén I., Negrete-Yankelovich, S. and Reyes-García, V. (2011). 'Community managed forests and forest protected areas: An assessment of their conservation effectiveness across the tropics.' Forest Ecology and Management 268, 217. doi.org/10.1016/j.foreco.2011.05.034

Rights and Resources Initiative (2012). What rights? A Comparative Analysis of Developing Countries' National Legislation on Community and Indigenous Peoples' Forest Tenure Rights. Washington, DC: Rights and Resources Initiative.

Rights and Resources Initiative (2015). Protected Areas and the Land Rights of Indigenous Peoples and Local Communities: Current Issues and Future Agenda. Washington, DC: RRI.

Robson, J.P. and Berkes, F. (2010). 'Sacred Nature and Community Conserved Areas' in S. Pilgrim and J. Pretty (eds.), Nature and Culture: Rebuilding Lost Connections. Earthscan.

Rodriguez, C., van der Hammen, M.C., Matapi, U., Yucuna, R. and Vargas, C. (2014). 'Environmental governance in the Colombian Amazon,' in Chavez-Tafur J. and R.J. Zagt (eds.) Towards Productive Landscapes. Wageningen, the Netherlands: Tropenbos International.

Shahabuddin, G. and Rao, M. (2010). 'Do community conserved areas effectively conserve biodiversity? Global insights and the Indian context.' Biological Conservation 12:3. doi.org/10.1016/j.biocon.2010.04.040 
Stevens, S. (ed.) (1997). Conservation Through Cultural Survival: Indigenous Peoples and Protected Areas. Washington, DC: Island Press. doi.org/10.2307/215879

Stevens, S. (2010). 'Implementing the UN Declaration on the Rights of Indigenous Peoples and International Human Rights Law Through the Recognition of ICCAs' IUCN-CEESP Policy Matters 17: 181.

Stevens, S. (ed.) (2014). Indigenous Peoples, National Parks and Protected Areas: A New Paradigm Linking Conservation, Culture and Rights. Tucson AZ: University of Arizona Press.

Stevens, S., Jaeger T. and Pathak Broome, N. with BorriniFeyerabend, G., Eghenter, C., Jonas, H.C. and Reyes G. (2016a). ICCAs and Overlapping Protected Areas Fostering Conservation Synergies and Social Reconciliation. Policy Brief of the ICCA Consortium, Issue No. 4. Teheran, Iran: ICC Consortium.

Stevens, S., Jaeger, T., and Pathak Broome, N., with Aylwin, J., Azhdari, G., Bibaka, D., Borrini-Feyerabend, G., Colchester, M., Dudley, D., Eghenter, C., Eleazar, F., Farvar, M., Frascaroli, F., Govan, H, Jonas, H.C., Kothari, A., Reyes, G., Singh, A., and Vaziri, L. (2016b). Recognising and Respecting ICCAs Overlapped by Protected Areas, Report for the ICCA Consortium.

Stolton, S. and Dudley, N. (2006). Measuring Sustainable Use: A method to assess the conservation benefits from sustainable management outside protected areas and to include this information in ecoregional planning. UK: Equilibrium Research.

Tauli-Corpuz, V. (2016). Conservation and Indigenous Peoples' Rights $(A / 71 / 150)$. Report to the $71^{\text {st }}$ Session of the UN General Assembly.
Tobin, B. (2014). Indigenous Peoples, Customary Law and Human Rights: Why Living Law Matters. Routledge. doi.org/10.4324/9781315778792

United Nations (2009). State of the World's Indigenous Peoples. New York, NY: UN.

UNEP-WCMC and IUCN (2016). Protected Planet Report 2016. Cambridge UK and Gland, Switzerland: UNEP-WCMC and IUCN.

UNEP-WCMC and IUCN (2017). Protected Planet: The World Database on Protected Areas (WDPA) On-line, July 2017, Cambridge, UK: UNEP-WCMC and IUCN. Available at: www.protectedplanet.net.

Vasseur, L., Horning, D., Thornbush, M., Cohen-Shacham, E., Andrade, A., Barrow, E., Edwards, S., Wit, P. and Jones, M. (2017). Complex problems and unchallenged solutions: Bringing ecosystem governance to the forefront of the UN sustainable development goals. Royal Swedish Academy of Sciences. doi.org/10.1007/s13280-017-0918-6 doi.org/10.1038/sdata.2016.67

Verschuuren, B., Wild, R., McNeely, J., and Oviedo, G. (2010). Sacred Natural Sites: Conserving Nature and Culture. London, UK: Earth Scan. doi.org/10.4324/9781849776639

Watson, J., Darling, E., Venter, O., Maron, M., Walston, J., Possingham, H., Dudley, N., Hockings, M., Barnes, M. and Brooks, T. (2015). 'Bolder Science Needed Now for Protected Areas.' Conservation Biology doi.org/10.1111/ cobi.12645

White, A., Molnar A., and Khare, A. (2004). Who Owns, Who Conserves, and Why it Matters. Washington D.C: Forest Trends.

Wilk, R. (1995). 'Learning to be local in Belize: global systems of common difference' in Miller, D (ed.), Worlds apart: 


\section{RESUMEN}

Este artículo refleja los progresos en curso de la UICN en lo tocante al desarrollo de una guía técnica sobre "otras medidas eficaces de conservación basadas en áreas" (OECM, por sus siglas en inglés) y comienza a explorar bajo qué condiciones las OECM - como una nueva forma de reconocimiento- podrían contribuir positivamente a los territorios y áreas conservadas por pueblos indígenas y comunidades locales (ICCA, por sus siglas en inglés). En él se argumenta que, si bien el marco de áreas protegidas es un medio potencialmente útil para reconocer las contribuciones a la biodiversidad de algunos ICCA, no es universalmente válido. En este contexto, y sujeto a importantes advertencias, los marcos relacionados con las OECM ofrecen una buena oportunidad para aumentar el reconocimiento y el apoyo para los ICCA. El artículo concluye con dos recomendaciones prácticas: en primer lugar, para la elaboración de orientaciones complementarias sobre las OECM y los ICCA; y, en segundo lugar, para un debate más amplio entre las diversas partes interesadas con respecto a si las "OECM" deberían denominarse "áreas conservadas".

\section{RÉSUMÉ}

Ce document reflète les progrès continus de l'UICN pour élaborer des directives techniques concernant les 'autres mesures de conservation efficaces par zone' (OECM, selon le sigle en anglais) et commence à explorer dans quelles conditions les OECM - en tant que nouvelle forme de reconnaissance - pourraient apporter une contribution positive aux territoires et aires conservées par les peuples autochtones et les communautés locales (APAC). Il fait valoir que si les aires protégées présentent un cadre potentiellement utile pour reconnaître les contributions de certaines APAC en matière de biodiversité, ce cadre n'est pas universellement approprié. Dans ce contexte, et sous réserve de mises en garde importantes, la structure des OECM offre une opportunité importante d'accroître la reconnaissance et le soutien aux APAC. Le document se termine par deux recommandations pratiques : d'abord l'élaboration d'orientations supplémentaires pour les OECM et les APAC; et deuxièmement, la poursuite de discussions par un large éventail de parties intéressées sur la question de savoir si les 'OECM' pourraient être qualifiées d' 'aires protégées'. 